\title{
Rural development strategies and government roles in the development of farmers' cooperatives in China
}

\author{
Aijuan $C^{2}{ }^{a *}$ and Steffanie Scott ${ }^{\mathrm{b}}$ \\ University of Waterloo
}

Submitted August 1, 2013 / Revised November 18, 2013, and February 24, March 25, June 13, and July 3, 2014 / Accepted June 13, 2014 / Published online September 8, 2014

Citation: Chen, A., \& Scott, S. (2014). Rural development strategies and government roles in the development of farmers' cooperatives in China. Journal of Agriculture, Food Systems, and Community Development, 4(4), 35-55. http://dx.doi.org/10.5304/jafscd.2014.044.005

Copyright (C) 2014 by New Leaf Associates, Inc.

\begin{abstract}
In an effort to address the growing income disparities between rural and urban residents in China, Chinese authorities introduced a series of rural development policies beginning in 2002 that established as a national goal a xiaokang (all around better off) society and gave top priority to the triad of agriculture, rural areas, and farmers. Farmers' cooperatives, consequently, have received substantial government support since 2002 as they are viewed as an important institution for linking small-scale producers to agro-food supply chains, and particularly value-added food chains. Yet little is understood regarding how and to what extent

\footnotetext{
a* Corresponding author: Aijuan Chen, PhD candidate, Department of Geography and Environmental Management, University of Waterloo; 200 University Avenue West; Waterloo, Ontario, N2L 3G1, Canada; a34chen@gmail.com

b Steffanie Scott, Associate Professor, Department of Geography and Environmental Management, University of Waterloo; 200 University Avenue West; Waterloo, Ontario, N2L 3G1, Canada; +1-519-888-4567 x37012;
} sdscott@uwaterloo.ca
\end{abstract}

farmers' cooperatives have benefited members and contributed to rural development in China. Using a case study method and in-depth interviews, we evaluated three successful farmers' cooperatives in China. Following the "deepening-broadeningregrounding" typology proposed by van der Ploeg, Long, and Banks (2002), we found that the farmers' professional cooperatives can make important economic, social, and environmental contributions to rural development by adopting alternative strategies and activities. On the other hand, these cooperatives also face great challenges for further development, including limited access to land and capital, a massive loss of laborers, low market competitiveness, weak internal management, and limited government support, which explains why cooperatives are not more widespread in China. This paper offers new insights into the roles of farmers' cooperatives and government in rural development.

\section{Keywords}

China, ecological agriculture, farmers' professional cooperatives, sustainable rural development 


\section{Introduction}

Under the agro-industrial paradigm, agricultural producers face a reduction in economic margins as a result of the cost-price squeeze (van der Ploeg, 2000). Small-scale farmers in developing countries face numerous challenges in connecting to agricultural services and in accessing markets, especially value-added markets (Barrett, 2008; Kruijssen, Keizer, \& Giuliani, 2009). By working collectively, farmers' cooperatives can significantly reduce transaction costs and increase the bargaining power of farmers in the supply chain (Bosc, Eychenne, Hussein, Losch, Mercoiret, Rondot, \& MackintoshWalker, 2002). Compared with the capitalist agribusiness model, this model has the potential to be more inclusive of the most resource-poor, smallscale farmers (Kruijssen et al., 2009). Kirschenmann, Stevenson, Buttel, Lyson, and Duffy (2008) view this model as "an encouraging trend with real benefits to the local communities" (p. 3).

Farmers' professional cooperatives (FPCs) have grown rapidly in rural China over the past 10 years. They have become an important institution in rural China in attempting to achieve the vertical integration of agricultural production, processing, and marketing. However, findings about FPCs are controversial. Realizing the potential to combine capitalist and socialist components, Huang (2011) advocates FPCs as alternatives to large agribusiness companies for integrating small-scale farms with processing and marketing, and predicts that FPCs could outcompete agribusiness if they were given the same state subsidies and privileges. Others suggest that FPCs would likely be transformed into capitalist agribusiness and be cooperatives in name only if farmers could not sustain anticapitalist political mobilization (Hale, 2013; Lammer, 2012). Gürel (2014) further points out that many FPCs in contemporary China are company-like cooperatives that are similar to agribusiness in terms of their "shareholding and decision making structures and the production relations they facilitate" (p. 69).

These critiques tend to apply only to coops established by enterprises. Rather than continuing the debate on "true" and "fake" cooperatives, we argue that FPCs - particularly the subset of cooperatives that are not merely extensions of agroenterprises - have the potential to make significant social, economic, and environmental contributions to rural development in China by adopting the "deepening-broadening-regrounding" framework proposed by van der Ploeg, Long, and Banks (2002). In this study we analyze how new entrepreneurial and innovative strategies are pursued, what roles are played by the Chinese government in the establishment and operation of FPCs, and what roles are played by different farm members and their participation in decisionmaking and profit-sharing. Finally, we analyze the main contributions to rural development and the development challenges of FPCs.

This paper is structured as follows. We first present the research framework adopted in this study to analyze the convergence of farmers' cooperatives to rural development. Next, we introduce the methods used in data collection and analysis for this study. Then we provide a brief overview of FPC development in China. We then introduce three cases of FPCs and highlight the government's role in promoting FPCs. Finally, we analyze the contributions of FPCs and the challenges they face.

\section{Convergence of Farmers' Cooperatives and Sustainable Rural Development}

Based largely on Europe's experience, Terry Marsden (2003) identifies three distinct agrarian production paradigms that link rural development to sustainable development: the "agro-industry paradigm," the "post-productivist paradigm," and the "sustainable rural development paradigm." These three paradigms differ in internal logic, ideology, scientific rationality, and regulatory arrangement (Marsden, Banks, \& Bristow, 2002). The agro-industrial paradigm, following the logic of neoclassical economics, promotes specialization and economies of scale. The post-productivist paradigm is based on the belief that the agricultural sector (in developed economies) is being marginalized through a move away from food production and toward the "consumption" of the countryside (Marsden, Murdoch, Lowe, Munton, \& Flynn, 1993). Marsden (2003) argues that both of these two development paradigms are unsustainable.

In contrast to these two paradigms, the new sustainable rural development paradigm redefines our relationship with nature by highlighting the 
multifunctionality of agriculture and works toward an alternative food supply chain to counter the scale and price rationalities of large-scale agribusiness (Marsden et al., 2002). The rural development paradigm explores opportunities in the agricultural sector related to resource use, livelihood strategies, and institutional arrangements. This paradigm reasserts land-based agricultural production as a central dimension in achieving rural sustainability and highlights the crucial roles of farmers and farmers' cooperatives in revitalizing the rural economy (van der Ploeg et al., 2000; Marsden et al., 2002). It emphasizes the ability and skills of famers and PFCs to generate different economic values from the same ecological resource through co-production, cooperation and coevolution of the resource base (Marsden, 2009). The multifunctional role of agriculture in meeting new social and environmental demands is underlined in this paradigm (Renting et al., 2009; van der Ploeg, Laurent, Blondeau, \& Bonnafous, 2009).

\section{Figure 1. Boundary Shifts: The "Deepening-Broadening-Regrounding" Typology}

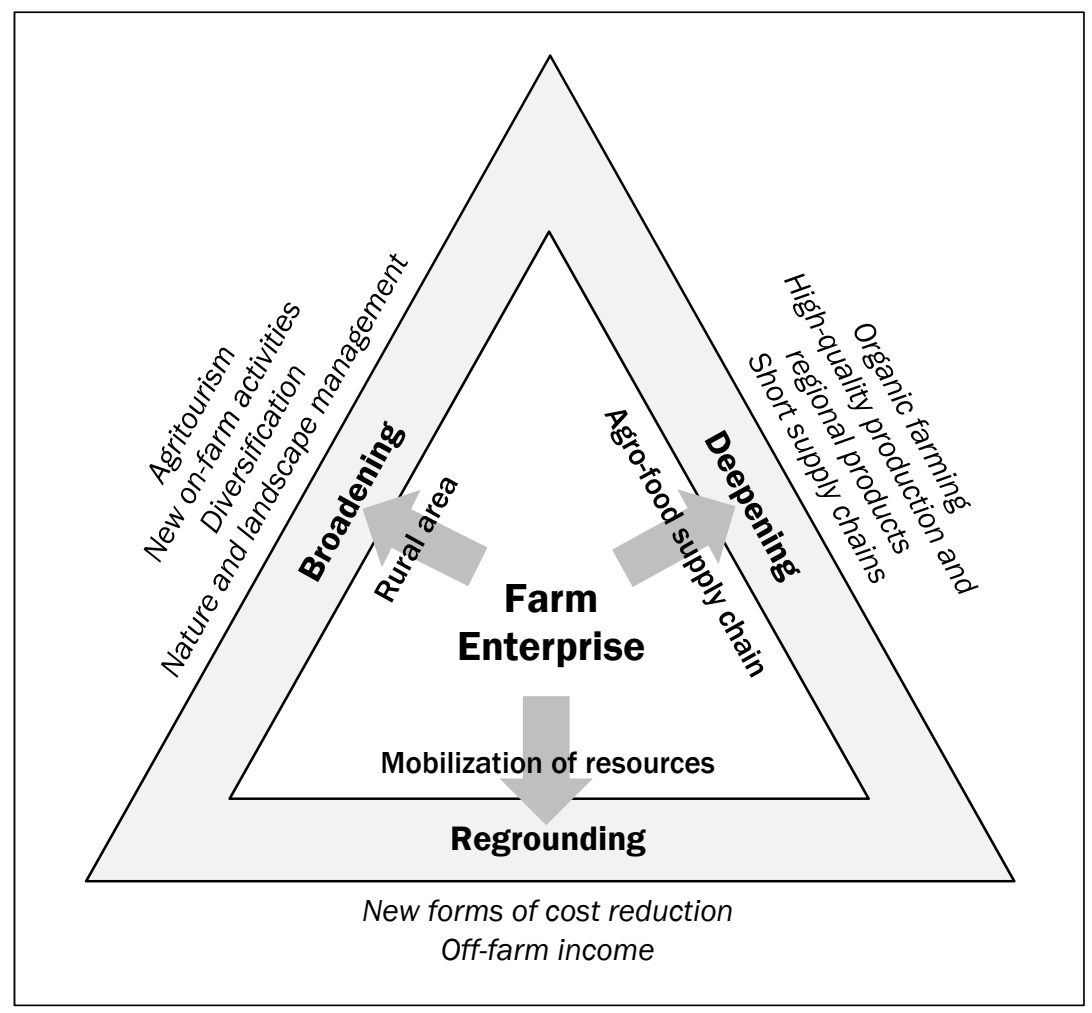

Source: Van der Ploeg, Long, \& Banks, 2002, as cited in Van der Ploeg et al., 2012, p. 134.
Although the rural development paradigm has been widely used, there is no comprehensive and agreed upon definition of it (van der Ploeg, 2000). Part of the debate concerns the role and categorization of rural development activities. To identify an activity as a "rural development activity," Marsden, Banks, and Bristow (2002) postulate that the aggregated effect of this activity must meet the following three conditions: (1) it is a response to the cost-price squeeze on agriculture and adds income (and/or employment opportunities) to the agricultural sector; (2) it corresponds to the needs and expectations of the population and expresses new relationships between the agricultural sector and society; and (3) it implies a redefinition, recombination, and/or reorganization of rural resources and develops new businesses and/or opportunities within rural society. The diversified activities can take place on-farm and/or within the local economy, either within the scope of agriculture or outside of it (van der Ploeg et al, 2002). Beyond the production of raw materials, alternative activities include landscape management, agritourism, innovative forms of cost reduction, production of high quality and region-specific products, direct marketing, and new activities such as care activities for the disabled (Darnhofer, 2005, p. 309).

Van der Ploeg et al. (2002) propose a typology of alternative farming strategies to categorize diversified rural development activities: "deepening," "broadening," and "regrounding" (see Figure 1). A deepening strategy refers to activities that add value to products by means of processing or by focusing on "quality" production (such as organic) or shortening the food supply chain. A broadening strategy refers to activities that diversify nonagricultural activities based on rural resources, such as agritourism and landscape con- 
servation. A regrounding strategy refers to activities that reorganize farm resources mainly through reallocating family labor, reutilizing farm resources, or adopting various forms of local and regional cooperation and/or collaboration to achieve cost reductions.

To better accommodate the situation in China, we adopt this typology in the current study with two slight modifications: (1) we consider green, hazard-free, ${ }^{1}$ and organic agriculture as ecological agriculture under the category of deepening strategy in this paper (see Scott, Si, Schumilas, \& Chen, 2014, for the differences between organic, green, and hazard-free certification); and (2) we do not consider off-farm income to be a regrounding strategy for FPCs. Part-time farming is a common phenomenon in rural China, so it should not be viewed as an alternative farming activity. Moreover, the effects of part-time farming on rural development in China are contradictory, as we explain later in this paper.

The deepening-broadening-regrounding typology provides an analytical framework for describing and assessing agricultural multifunctionality and rural sustainability. Beyond producing food and fiber, and providing employment and income, agriculture is considered to be one of the most common multifunctional activities, which also produces other commodities (such as agritourism and other services) and noncommodity outputs (such as landscape management, soil conservation, and biodiversity) (Durand \& van Huylenbroeck, 2003; Renting et al., 2009). With a few exceptions (van der Ploeg, Jingzhong, \& Schneider, 2012), this framework has been applied to date mainly within EU rural-development contexts (see for example OrtizMiranda, Moreno-Pérez, \& Moragues-Faus, 2010).

Rural development research often starts at the farm or farm household levels, although it is also

\footnotetext{
${ }^{1}$ Given the fact that GMO and certain types of pesticides and fertilizers are allowed in production, green and hazard-free production practices would not be considered as ecological agriculture in a European or North American context. We categorize green and hazard-free production practices under "ecological agriculture" sector in this paper because they have a tendency toward reducing ecological impact by limiting the usage of agro-chemicals (in terms of both amounts and types) compared with conventional farming practices in China.
}

valuable to conduct studies at the regional level in order to examine connections to rural life more widely and to other (economic) actors operating in the countryside (Knickel \& Renting, 2000). The farmers' cooperative model provides an important lens to analyze rural development at the regional level, although to date this model has received little attention in rural development research (OrtizMiranda et al., 2010). Following the deepeningbroadening-regrounding typology, we examine the potential contributions of FPCs to agricultural multifunctionality and rural development in China.

\section{Research Methods}

The research was designed as a multiple case study (Yin, 2003), consisting of three cases of cooperatives involved in China's ecological and organic agriculture sector. Each of these three Daizhuang Organic Farmers' Professional Cooperative in Jiangsu province, Tonglu Peach FPC in Zhejiang province, and Yuexi Organic Kiwifruit FPC in Anhui province - represents an FPC initiated and established by different types of internal or external actors. The cooperatives that we selected reflect the following three criteria:

(1) They all follow the principles stated in the Farmers' Professional Cooperative Law, ${ }^{2}$ although all three FPCs existed before the law was enacted.

(2) The cooperatives were initiated and established differently: by large-scale farms, by agro-industries, and by other external actors (such as researchers, government agents, foreign donors, and nongovernmental organizations $[\mathrm{NGOs]}) .^{3}$

\footnotetext{
2 According to the Farmers' Professional Cooperative Law, implemented in 2007, FPCs should follow five principles: (1) farmers play the dominant role in the cooperative; (2) the key purpose is to serve members and act in the common interests of all members; (3) the members shall join and exit voluntarily; (4) all members are equal and cooperatives are democratically controlled; and (5) surplus should be redistributed based on the volume of members' patronage (National People's Congress [NPC], 2006: article 3, chapter 1, paragraph 4). ${ }^{3}$ Cooperatives initiated by agro-enterprises are not included in this study because agro-enterprises are mainly driven by profit maximization rather than a rural development goal. Clegg
} 
(3) They all adopt "alternative" farming strategies and have been relatively successful economically.

We chose to focus on successful cases to better understand the contributions of cooperatives to rural development. Moreover, we selected cases adopting "alternative" farming strategies in order to demonstrate the kinds of new opportunities that are emerging for farmers' cooperatives based on the growing demand for high quality and organic food, especially in China's domestic market ( $\mathrm{Si}$, Schumilas, \& Scott, in press). We recognize, however, that most cooperatives in China are still oriented to conventional agricultural production.

Both primary and secondary data were used in this study. Primary data were collected through face-to-face semistructured interviews. Over 20 interviews were conducted between 2010 and 2012. ${ }^{4}$ Interviewees were selected using purposive sampling and included the cooperative initiators, cooperative leaders, cooperative members, and organic certification agencies, as well as other key actors such as representatives from local institutions and government agencies. At least four interviews focused specifically on each of the FPC cases, including one with each cooperative leader. All interviews were conducted in person and took on average 60 minutes to complete. Interviews were conducted in Chinese, and notes were written in Chinese during each interview and translated into English later. In addition to this interview data, we also reviewed secondary sources in this study, including government reports, project reports of organic agricultural development in less-developed regions, and cooperative documents of Tonglu and Daizhuang FPCs. NVivo, a qualitative data analysis

(2006) found that the agro-industrial-oriented model in China leads to the monopolization of benefits by wealthy farmerinvestors and outside shareholders at the expense of smallscale farms. Moreover, this model does not address the disadvantaged position of small-scale farms in decision-making and in the distribution of earnings (see Yan \& Chen, 2013, regarding the intellectual debate over rural cooperatives in China).

${ }^{4}$ This is part of a larger project on "Greening China's food system: The emerging alternative and ecological agriculture sector" that has involved 106 interviews with six types of key stakeholders. computer software package for working with textual data, was used to code and inductively categorize data into themes.

\section{The Development of Farmers' Cooperatives in China}

Internationally, cooperatives have been a central institution in social development, poverty alleviation, employment creation, and participatory development (United Nations, 2001). The cooperative model is defined by the International Co-operative Alliance (ICA) as "an autonomous association of persons united voluntarily to meet their common economic, social, and cultural needs and aspirations through jointly-owned and democraticallycontrolled enterprise" (n.d., para. 1). Cooperatives can deliver pro-poor growth in a manner that is owned and controlled by poor and small-scale farmers themselves (Clegg, 2006). Nevertheless, farmers' cooperatives in developing countries face many challenges due to the lack of capital and business management capacity (Birchall, 2004).

The development of farmers' cooperatives since the establishment of the People's Republic of China in 1949 can be divided into three phases: from 1949 to the early 1980s, the early 1980s to 2007, and 2007 to the present. Since 1949, agrarian institutions have changed from agricultural "collectives" or people's communes in the Mao era ${ }^{5}$ to family farming and then to FPCs (Jia, Hu, Hendrikse, \& Huang 2010). The unsuccessful experience of agricultural collectives during the Maoist period became an obstacle to developing farmers' cooperatives in the following decades. The level of trust among people - an important basis for cooperation - was eroded in many systems of collectivization due to centralized decision-making that left little or no room for civil society initiatives and social organizations (Paldam \& Svendsen, 2002). Subsequent challenges have been reported

\footnotetext{
${ }^{5}$ We use the phrase "collective" here to refer to the type of collective action with the purpose to overcome barriers faced by individual farms. Although in the Chinese literature "collective" is sometimes translated into English as "cooperative," we recognize that "collective farms" in the Mao era would not be considered cooperatives today. The "collectives" in the Mao era did not meet the criteria of cooperatives, such as being voluntary to join or withdraw.
} 
in some post-socialist countries with (re)establishing farmers' cooperatives (see Paldam \& Svendsen, 2002; Tisenkopfs, Kovách, Lošt’ák, \& Šūmane, 2010). Agricultural collectives in China stagnated between the 1960s and early 1980s. Cooperatives began to emerge, particularly in the fruit and vegetable sectors (Garnevska, Liu, \& Shadbolt, 2011), in the late 1980s, with the shift from central planning to market orientation in the agricultural economy (Xiaoshan, 1999). These cooperatives mainly involved pre- and post-farm production activities in relation to purchasing farm inputs, processing, and marketing (Clegg, 2006).

Experiences of the "East Asia development model" in Japan, South Korea, and Taiwan indicate that rural development often garners more attention when the industrialization and urbanization of a country reach a certain phase. To build a stronger rural community and improve the living conditions of rural households, community-based rural development initiatives, especially farmers' cooperatives, have been promoted in these countries through policy support (Choi, Kim, Kim, \& Kim, 2007; Long, Liu, Li, \& Chen, 2010). Scholars argue that China reached a turning point for rural development in the 2000s in terms of per capita gross domestic product (GDP), which was US $\$ 1090$ in 2003 (Long et al., 2010). The fast-growing economy and stronger international standing mean that China is in a position to broaden its development strategy and provide more support to agricultural and rural development. China can learn from South Korean and Japanese experiences and build a new countryside by establishing farmers' cooperatives to encourage local participation (Long et al., 2010).

The first national Farmers' Professional Cooperative Law was implemented in 2007 to formalize and standardize FPCs in China. The law stipulates that FPCs must be voluntarily and democratically organized and remain independent in operation. Having FPCs controlled democratically by farmers sets them apart from the previous agricultural collectives of the socialist era, in which the supplying of farming inputs and producing and selling activities were all centrally planned by government (Hu, Reardon, Rozelle, Timmer, \& Wang, 2004). The stable legal environment together with various supportive government policies has created a favorable political and economic environment for developing FPCs in China. As a result, the number of FPCs has been increasing rapidly since 2007 (see Table 1). However, most FPCs are criticized for being "fake" cooperatives that are controlled by a small group of members and fail to empower small producers in practice (Yan \& Chen, 2013). The "fake" cooperatives, mainly those initiated by agroenterprises, are different from the types that we examine in this study. Meanwhile, cooperation among FPCs across multiple townships is also developing in China; this increases their market power and provides more services for farm members (Garnevska, Liu, \& Shadbolt, 2011).

The main activities defined in the law include purchasing agricultural inputs, marketing, processing, transportation, storage, and providing agricultural technology and information. Learning from the experience of "comprehensive cooperation" in Japan, South Korea, and Taiwan, many Chinese rural development advocates and intellectuals (e.g., Wen Tiejun and Li Changping) also highlight the values of FPCs in empowering rural areas and small producers rather than focusing only on commodity production (Yan \& Chen, 2013). In situations where farmers are poorly educated, lack
Table 1. Farmers' Cooperatives Registered at the Bureaus of Industry and Commerce in China, 2007-2012

\begin{tabular}{lccc}
\hline & $\begin{array}{c}\text { Number of registered } \\
\text { farmers' cooperatives }\end{array}$ & $\begin{array}{c}\text { Number of } \\
\text { registered members }\end{array}$ & $\begin{array}{c}\text { Registered capital } \\
\text { (millions of US\$ª }\end{array}$ \\
\hline $\mathbf{2 0 0 7}$ & $\mathbf{2 6 , 4 0 0}$ & 350,000 & 5,074 \\
\hline $\mathbf{2 0 0 8}$ & 110,900 & $1,417,100$ & 14,329 \\
\hline $\mathbf{2 0 0 9}$ & 246,400 & $3,917,400$ & 40,070 \\
\hline $\mathbf{2 0 1 0}$ & $\mathbf{3 7 9 , 1 0 0}$ & $7,155,700$ & 74,002 \\
\hline $\mathbf{2 0 1 1}$ & 521,700 & $11,964,300$ & 117,950 \\
\hline $\mathbf{2 0 1 2}$ & 689,000 & n/a & 179,072 \\
\hline
\end{tabular}

a One US\$ was valued at 6.14 Chinese Yuan (Renminbi or RMB) as of August 2014. Source: Fleischer, 2012, p. 24; data from Ministry of Industry and Commence, and the General Station of Administration on Rural Cooperative Economy, Ministry of Agriculture. 
cooperative management experience, and have limited access to legal advice, intellectuals who advocate for rural development have called on the Chinese government (at both national and local levels) to play a stronger role in promoting and organizing FPCs (Yang \& Wen, 2011). With the strong support that the Chinese government has been giving to large-scale agribusiness enterprises, also called "dragon-head enterprises," since the mid-1990s, the capacity of cooperatives has suffered (Wen \& Dong, 2010). Yang and Wen (2011) call for stronger government support for developing cooperatives that "ensure fairness and protect the disadvantaged" and "represent integrative and long-term social interests" (p. 45).

The development of FPCs in different parts of China has been quite uneven. Cooperatives are developing rapidly in eastern China, where the economy and markets are more developed and agriculture is more industrialized, whereas cooperatives in less industrialized western China are still in the early stages of development (Liang \& Hendrikse, 2013). Zhejiang is a pioneering province in eastern China where the first modern farmers' cooperatives in China were established. Zhejiang takes the lead in the development of farmers' cooperatives in China, both in terms of the total number of FPCs and their economic performance (Liang \& Hendrikse, 2013; Sultan \& Larsén, 2011). It was also a leading province in enacting the provincial cooperative law and regulations in 2005, providing the basis for the national law ${ }^{7}$ promulgated on July 1, 2007.

In the following section, we outline three case studies that exemplify successful examples of developing economies of scope in FPCs to achieve agrarian-based forms of rural development. We begin by highlighting the socio-economic context

\footnotetext{
${ }^{6}$ Dragon-head enterprises are "clustered groups to which state capital can be channeled and state preferential treatment provided" (Chan, 2009, p. 46).

${ }^{7}$ In China, provinces or municipalities are allowed and selected (in some cases) to experiment with new projects or strategies in a given area, and then the state learns from this and the experience shapes the national law. This differs from the procedure in many other countries, where a law is enacted and then people follow it in a much more linear system than in China (also see van der Ploeg et al., 2012).
}

of each case. The practices and strategies pursued by the three FPCs are analyzed according to deepening, broadening, and regrounding strategies. We also examine the role played by the Chinese government in promoting cooperatives.

\section{Findings}

\section{Cooperative Profiles}

Daizhuang Organic FPC: Daizhuang village, south of Jurong city in Jiangsu province, is situated on hilly land with 1,040 hectares or 2,570 acres (approximately 666.7 hectares or 1,648 acres of farmland, 60 percent of which is hilly-slope land) and a population of 2,900 (around 866 households). At the time of establishing the cooperative, it was the poorest village within Zhenjiang City, despite boasting rich natural resources. Before the establishment of the Daizhuang Organic FPC, conventional crops, including wheat and rice, were produced. After a comprehensive study, a senior researcher, Mr. Zhao at the Institute of Zhenjiang Agricultural Technology \& Science (IZATS), facilitated the establishment of this cooperative in 2006. Since that time, Mr. Zhao has continued to serve as an on-site technical consultant, and the village secretary has served as the cooperative leader, ${ }^{8}$ attending to the daily management of activities in the cooperative. Daizhuang Organic FPC was the first organic farmers' cooperative in Jiangsu province. Its main products are organic rice and strawberries. Products are sold through various channels, including direct sale to companies ${ }^{9}$ (60 percent of sales), to individuals (20 to 30 percent), through its own specialty stores locally, and via agencies in large cities. Home delivery was offered in 2007 and 2008 but was discontinued due to the high cost. Given the small volume of production, this cooperative faces challenges in supplying a large food retailer. $^{10}$

\footnotetext{
${ }^{8}$ Given that many young people have migrated to urban areas for better job opportunities, secretaries are often the ones with a better education and stronger ability than others in rural areas.

${ }^{9}$ In China, it is common for an employer to purchase gifts for employees or clients on special occasions throughout the year. 10 The large retailer refers in particular to Beijing Organic and
} 
Tonglu Peach FPC: Yangsanfan village, in the northern part of Tonglu county, in Zhejiang province, is situated in a mountainous area with 519 hectares or 1,282 acres (approximately 74 ha or 183 acres of farmland and 155 ha or 383 acres of forest land) and a population of 861 (285 households). Peaches have been grown in this area for approximately 170 years. Compared to other areas in China, rural communities in Zhejiang province are wealthier and farmers have greater entrepreneurial skills. The per capita income in this village was around US\$2,000 in 2008. With the support of local government agencies, the Tonglu Peach FPC was initiated in 2004 by a few local "large-scale" peach farmers, ${ }^{11}$ which is the first farmers' cooperative in Tonglu county. Mr. Wang, one local large-scale peach farmer, has acted as the elected cooperative leader since its founding. He is highschool educated and is active in marketing and establishing social networks. Peaches and cherries are the main products of this cooperative. Peaches

Beyond Corporation $(\mathrm{OABC})$, which is one of the largest companies engaging in the cultivation, production, distribution, and home delivery of organic food in China. Although this company has its own production bases, it also buys organic products from enterprises or cooperatives. FPCs also face great difficulties in selling their products through supermarkets, the major food outlets in most cities, partially due to the small volume of their production and the high standards that must be met. It is also costly to sell products through supermarkets, including paying stocking, sales, and promotional fees, and giving 20 percent of the profit to the store (Lagos, Scott, Rasmussen, Bugang, \& Chen, 2010). Therefore many FPCs choose to sell their products at wholesale markets or via direct marketing channels (as we illustrated in the three cases discussed here).

${ }^{11}$ We recognize that there are significant differences in definitions and in the understanding of what constitutes a smallversus large-scale farm in China and the west. In this study, small-scale farming refers to Chinese family farms with an average size of less then 0.5 hectare or 1.2 acres per household, whereas large-scale farming refers to farm sizes over 1.3 hectares or 3.2 acres. During our interviews from 2010 to 2011, farms with sizes over $20 \mathrm{mu}$ (or 1.3 hectares or 3.2 acres) were referred to by several cooperative leaders as large-scale farms. Some of these farms lease land from their relatives or neighbors who choose to work in non-agricultural sectors in cities; others lease undeveloped village land from rural collectives. The latter often have comparatively larger scales (e.g., over 50 mu or 3.3 hectares or 8.2 acres) as we have seen in the Tonglu case. are sorted into two grades: first-class peaches are gift packaged and are procured by companies and government agencies as gifts for employees ${ }^{12}$ or are sold at specialty fruit markets in large cities; second-class peaches are sold at wholesale markets. Agritourism is also a channel for this cooperative to sell its products.

Yuexi Organic Kiwifruit FPC: Yufan village in Yuexi county, Anhui province, is situated in a cool mountainous area with 950 hectares or 2,348 acres (approximate 95 ha or 235 acres of farmland, 68 percent of which is paddy field and the rest is dry land, and 850 ha or 2,100 acres of forest land) and a population of 1,005 ( 257 households). It is the poorest village in the area. The Yuexi Organic Kiwifruit FPC ${ }^{13}$ was established in 1999 in Yufan village with the support of a Deutsche Gesellschaft für Technische Zusammenarbeit (GTZ) project, ${ }^{14}$ the Organic Food Development Center (OFDC), ${ }^{15}$ and the local government. The cooperative produced organic kiwifruit and water bamboo. Mr. $\mathrm{Chu}$, a former village officer, has served as the elected cooperative leader because he knows the local situation well and is willing to devote himself to local development. Following the end of GTZ project support in 2003, the organic kiwifruit FPC was divided into two groups in 2006: the kiwifruit FPC and the water bamboo FPC. The latter has

\footnotetext{
12 This cooperative, collaborating with several other cooperatives that produce different crop varieties in the same area, runs its own specialty stores and attracts local consumers.

13 This cooperative is supported by Yufan Kiwifruit Research Institute, which was founded by several local farmers in response to serious plant diseases and insect pests suffered by kiwifruit farmers in the village from 1991 to 1993 . With the technical support from the institute, kiwifruit production grew rapidly in the following 10 years, and this area became "the first township of kiwifruit production in East China" with over 290 ha (717 acres) under kiwifruit cultivation.

14 The Sino-German GTZ project (1998-2003), named "Development of Organic Agriculture in Poverty Areas in China," was initiated to offer an advisory service and information system in China for organic agricultural development. 15 The Organic Food Development Center (OFDC), founded in 1994 in Nanjing by the former Chinese State Environmental Protection Agency, is the first specialized organization engaged in research, certification, training, and promotion of organic agriculture in China. It is also one of the largest certification bodies in China.
} 
been growing rapidly. The withdrawal of the GTZ project posed a difficult challenge to the kiwifruit FPC to continue organic farming because of the high certification costs, a shortage of funding, and limited access to value-added markets to garner a sufficient price premium. As a result, the FPC discontinued organic kiwifruit farming. Organic kiwifruits had been exported with the assistance of the GTZ project, while non-organic kiwifruits have been sold domestically through various channels since the project support ended. Water bamboo is delivered to large cities (e.g., Shanghai, Nanjing, Hefei) and sold at wholesale markets. More recently, the retirement of the kiwifruit FPC leader also created difficulties as members lacked confidence in the new leader. Key characteristics of the three FPCs are summarized in Table 2.

\section{Alternative Strategies and the New Rural Development Paradigm}

The key function of FPCs is to provide services for their members. These services support on-farm activities (such as providing technical assistance and purchasing inputs together) and/or facilitate marketing their produce (such as sorting, grading, marketing, and processing). Activities and strategies adopted by the three FPCs can be grouped into the three categories of deepening, broadening, and regrounding (Table 3).

Deepening Strategy: All three FPCs have undertaken initiatives to increase the value of their products. Following Renting, Marsden, and Banks (2003), these initiatives can be considered to be new configurations of alternative food networks (AFNs). Three main types of deepening strategies were pursued. First, product branding was developed by all three FPCs with the goal of improving the reputation and market competitiveness of their products. Second, ecological and local characteristics of products (certified organic, green, hazardfree and geographical identification) were simultaneously highlighted in all three FPCs. These formalized standards and labels show the attributes of product quality and can help diversify marketing channels (Renting, et al., 2003). Although organic certification was not continued in the Yuexi FPC after the GTZ project withdrew in 2003, all water

Table 2. Key Characteristics of Three Professional Farmers' Cooperatives in China a

\begin{tabular}{|c|c|c|c|}
\hline & $\begin{array}{l}\text { Daizhuang FPC } \\
\text { (Jiangsu province) }\end{array}$ & $\begin{array}{l}\text { Tonglu Peach FPC } \\
\text { (Zhejiang province) }\end{array}$ & $\begin{array}{l}\text { Yuexi FPC } \\
\text { (Anhui province) }\end{array}$ \\
\hline Locations & $\begin{array}{l}\text { Close to large cities (Nanjing } \\
\text { and Shanghai) }\end{array}$ & $\begin{array}{l}\text { Close to large cities (Hangzhou } \\
\text { and Shanghai) }\end{array}$ & Far from large cities \\
\hline Initiators & $\begin{array}{l}\text { Several local farmers with } \\
\text { large-scale farmland }\end{array}$ & A researcher & $\begin{array}{l}\text { The GTZ project and the Organic } \\
\text { Food Development Center }\end{array}$ \\
\hline Leaders & A large-scale farmer & Local government official & Former local government official \\
\hline Year established & 2006 & 2004 & $\begin{array}{l}\text { Founded in } 1999 \text { and registered } \\
\text { in } 2001\end{array}$ \\
\hline $\begin{array}{l}\text { Number of } \\
\text { members }\end{array}$ & $\begin{array}{l}612 \text { households ( } 70 \% \text { of village } \\
\text { households) in } 2012 ; 3 \\
\text { households in } 2006\end{array}$ & $\begin{array}{l}173 \text { households ( } 60 \% \text { of total) } \\
\text { in } 2011 ; 116 \text { households in } \\
2004\end{array}$ & $\begin{array}{l}\text { No updated data (138 } \\
\text { households in 2002; } 43 \\
\text { households in 2001) }\end{array}$ \\
\hline $\begin{array}{l}\text { Technical } \\
\text { innovation }\end{array}$ & $\begin{array}{l}\text { Introduced a new rice variety } \\
\text { from Japan }\end{array}$ & $\begin{array}{l}\text { Applied new technology to } \\
\text { stagger the harvest time }\end{array}$ & $\begin{array}{l}\text { Promoted suitable crops for local } \\
\text { natural resources }\end{array}$ \\
\hline Main products & Organic rice and strawberries & $\begin{array}{l}\text { Peaches (green and hazard-free } \\
\text { certified) and cherries }\end{array}$ & $\begin{array}{l}\text { Kiwifruit and water bamboo } \\
\text { (hazard-free certified) }\end{array}$ \\
\hline Target markets & Domestic; various channels & $\begin{array}{l}\text { Domestic; gift packages \& } \\
\text { wholesale markets }\end{array}$ & $\begin{array}{l}\text { International (only for organic } \\
\text { kiwifruit) and domestic; } \\
\text { wholesale }\end{array}$ \\
\hline
\end{tabular}

a Most data listed in the table were supplied through interviews; additional information came from the report of the Yuexi Organic development Project 2002 (Bao, 2002) and cooperative documents of the Tonglu and Daizhuang FPCs.

b Most of the arable land in Yuexi county is cold, waterlogged paddy field, which is not suitable for growing regular crops (i.e., rice) and has low yields, but it is ideal for growing water bamboo. The Yuexi FPC took advantage of the local natural conditions and encouraged farmers to grow water bamboo. 
Table 3. Typology of Strategies Pursued by the Three Cooperatives

\begin{tabular}{llll}
\hline & Daizhuang FPC & Tonglu Peach FPC & Yuexi FPC \\
\hline $\begin{array}{l}\text { Deepening } \\
\text { strategy }\end{array}$ & $\begin{array}{l}\text { Product branding; food pro- } \\
\text { cessing; organic certification; } \\
\text { direct marketing }\end{array}$ & $\begin{array}{l}\text { Product branding; sorting and } \\
\text { packaging; green and hazard- } \\
\text { free certification; direct } \\
\text { marketing }\end{array}$ & $\begin{array}{l}\text { Product branding; organic certi- } \\
\text { fication; hazard-free certification; } \\
\text { geographical identification (GI) of } \\
\text { raw materials (water bamboo) }\end{array}$ \\
\hline $\begin{array}{l}\text { Broadening } \\
\text { strategy }\end{array}$ & Plan to develop agritourism & Flower Festival and agritourism & None \\
\hline $\begin{array}{l}\text { Regrounding } \\
\text { strategy }\end{array}$ & Unified farming management & $\begin{array}{l}\text { Unified farming management; } \\
\text { collaborating with other FPCs in } \\
\text { the same region to develop } \\
\text { agritourism }\end{array}$ & $\begin{array}{l}\text { Unified farming management; } \\
\text { collaborating with other FPCs in } \\
\text { the same region to transport } \\
\text { products to larger cities }\end{array}$ \\
\hline
\end{tabular}

bamboo produced in Yuexi county is hazard-free and geographical identification-certified. The Tonglu cooperative received hazard-free certification for 200 ha (949 acres) in 2005 and green certification for 67 ha (166 acres) in 2006. Peaches were sorted into two grades: first-class peaches for gift packages and second-class peaches for wholesale markets. The third type of deepening strategy, employed by the Daizhuang and Tonglu FPCs, was to use used direct-marketing strategies to sell most of their produce. The Yuexi FPC did not, due to the long distance from customers.

Broadening Strategy: At the time we conducted interviews, the Tonglu FPC was the only one among these three cases that developed a broadening strategy, although the leader of the Daizhuang FPC expressed strong interest in promoting agritourism. With the support of the Tonglu municipal government, the Tonglu FPC collaborated with several other FPCs in the same area to host visitors during the period of Flower Festival (lasting for four months from late March to midJuly). During the festival period, they organized many activities, including cultural performances, demonstrations of local agricultural products, tastings, sales, signing sales contracts, picking local fruits, and homestays with rural households. Agritourism (also called agritainment, experiencing life in a rural area) has become a popular form of rural tourism for many urbanites in China (Marsden, $\mathrm{Yu}$, \& Flynn, 2011). The leader of the Daizhuang FPC also viewed agritourism as a potential channel to sell its produce by hosting harvest festivals or other activities; it plans to develop agritourism in the near future. Agritourism was not mentioned in the Yuexi FPC, likely due to its distance from urban areas.

Regrounding Strategy: In terms of regrounding strategy, all three FPCs have developed and implemented unified farming management, which can reduce production and transaction costs on member farms by taking advantage of economies of scale. The FPCs made unified plans for farming activities (i.e., what, when, and how it is produced) to enable an adaptive response to increasingly differentiated market demands (such as quality requirements, seasons, product presentation). They also provided various services to their members, such as technical assistance and training; supplying ecological fertilizers and pesticides; supplying seeds and seedlings; and product processing, packaging and marketing. Collaborations among FPCs in the same region were adopted by the Yuexi and Tonglu FPCs to reduce the costs for transportation and for hosting events, respectively, even though these collaborations were informal and very loose. The leader of the Daizhuang FPC planned to combine crop cultivation and breeding (geese in this case) to offset the low productivity of organic rice farming and to increase farmers' income.

Compared to the deepening activities adopted by all three FPCs, the broadening activities are far less developed except agritourism in the Tonglu FPC. The adoption of non-agricultural activities is more challenging for FPCs. The underdevelopment of the broadening activities can be explained 
by the following reasons. First, some initial conditions are required to develop these kinds of activities. For example, an initial but significant investment is needed for developing and organizing agritourism in making rural areas attractive, such as providing accommodation facilities, arranging activities, and offering suitable opportunities for spending (Gannon, 1994). Considering the significance of the investment and the uncertainty of economic returns, an FPC is often unable or reluctant to invest in these facilities. Second, government needs to play an important role in funding and facilitating agritourism at the initial stage (Fleischer \& Felsenstein, 2000; Iorio \& Corsale, 2010). This poses challenges for developing agritourism in poor areas (for instance, Anhui province in our case study) where the local government has a more limited budget. The third reason for the underdevelopment of the broadening activities is that, besides economic constraints, developing non-agricultural activities and in particular agritourism often requires new skills such as guest services, marketing, and advertising (Sharpley, 2002), which are unfamiliar to farmers. In addition, collaboration among FPCs in the same region is important in developing agritourism, as we saw in the Tonglu FPC case (see also van der Ploeg et al., 2012).

\section{Membership and Internal Governance}

Based on the contributions in terms of land, labor, financial capital, and other social assets, cooperative members in an FPC can be divided into two main categories: core members (who are full-time farmers, often farming at comparatively large scales) and common or affiliate members (who are parttime farmers ${ }^{16}$ ).

According to our research, core members are often the village elite, including large-scale farmers, entrepreneurial farmers, business owners, and local government officials. These members generally hold more shares in the cooperative and correspondingly enjoy a greater share of its profits. They play an important role in initiating and promoting

\footnotetext{
16 Many "part-time" farmers in rural China work in cities during the slack farming season and return to their rural homes only in the busy farming season.
}

cooperative development by serving as the leaders of the cooperative and as members of the governing board. When we inquired about the qualities of an effective cooperative leader, the following characteristics were mentioned most frequently by cooperative members and leaders: having vision, business and management capacity, good education, ${ }^{17}$ and an enthusiasm for innovation; and being well-connected, open-minded, and committed to the cooperative. Local officials, who are also farmers in the villages, are often the best suited candidates to be cooperative leaders. Thus, as we saw in the Daizhaung and Yuexi cases, some village officials served as cooperative leaders. However, as we saw in these same two cases, the cooperative leader might not be the same person who initiates the cooperative, particularly in cases where cooperatives are initiated by external forces. The initiators often acted as an external connector in seeking out and providing financial, technical, and/or marketing support to the cooperative, while the leaders focus more on cooperative management and agricultural production.

Common members in all three FPCs appear to be similar in terms of their average size of landholding, age, and part-time farming status. In asking the cooperative leaders about the age, gender, and education characteristics of farm members in their cooperatives, we found that most members are farmers over 50 years old who have limited education. The governing board and core members normally participate more in decision-making regarding all stages of production and marketing, whereas the common members participate mainly in the production domain and are seldom involved in operational decision-making (see Table 4; also see Liang \& Hendrikse, 2013). According to the FPC law, everyone in the FPC has equal rights in

\footnotetext{
17 The education level of the rural population in China is relatively low, with an average of 6.5 years of schooling (Zhang, Huang, \& Rozelle, 2002). Approximately 14 percent of the rural population in China is illiterate or semi-illiterate (Fan \& Zhang, 2004). Considering the fact that migrants to urban areas are better educated than those who have not migrated (Zhao, 1999), the education level of the population who stay behind and continuing farming is lower. In this paper, the term "good education" refers to people with a level of secondary education or higher.
} 
Table 4. Membership and Decision-making in Three Cooperatives

\begin{tabular}{|c|c|c|c|}
\hline & Daizhuang FPC & Tonglu Peach FPC & Yuexi FPC \\
\hline Membership & $\begin{array}{l}\text { Core members (playing roles in } \\
\text { coop. management and } \\
\text { technical support) and common } \\
\text { members; members farming in } \\
\text { almost the same scale }\end{array}$ & $\begin{array}{l}\text { Core members (large-scale; } \\
\text { investing more capital) and } \\
\text { common members (small-scale) }\end{array}$ & $\begin{array}{l}\text { Core members (leasing large- } \\
\text { scale land; investing more } \\
\text { capital; delivering products to } \\
\text { urban markets) and common } \\
\text { members (small-scale) }\end{array}$ \\
\hline $\begin{array}{l}\text { Decision-making } \\
\text { among members }\end{array}$ & \multicolumn{3}{|c|}{$\begin{array}{c}\text { Core members decide on technical innovations and marketing issues, while common } \\
\text { members mainly just participate in production }\end{array}$} \\
\hline
\end{tabular}

decision-making (i.e., "one person one vote”), regardless of how much capital he or she has in the cooperative. The low participation of common members in FPC decision-making is largely due to lack of knowledge and information about technical innovations and marketing, being busy with offfarm work, and lack of interest (due to their small scale of farming and rapidly rising wages in nonagricultural sectors). ${ }^{18}$

\section{Government's Roles}

The Chinese government has played an important role in promoting farmers' cooperatives by implementing the Cooperative Law and developing a series of favorable policies. This has been particularly significant at the provincial and local government levels, although the extent of support varies by province, based on economic capacity. In recognizing the potential to improve farmers' production and marketing capacities, local governments have used administrative procedures, financial support, and other incentives to encourage the development of farmers' cooperatives within their jurisdictions. This can involve hosting mobilization meetings, providing technical training, arranging site visits for key members, assisting in and providing subsidies for certification for various ecological food standards, providing tax exemptions, and other kinds of financial support.

In this study, we found that the Daizhuang and Tonglu cooperatives receive more government support and are economically stronger than the Yuexi cooperative. This can be partially explained by the fact that Zhejiang and Jiangsu provinces are

\footnotetext{
18 Interview with the cooperative leaders and members in three FPCs in Anhui, Jiangsu, Zhejiang provinces, various dates, 2010-2011.
}

wealthier. ${ }^{19}$ However, we have too few cases in this study to be able to broadly conclude that cooperatives in wealthier provinces or regions tend to be stronger and receive more government support than those in less well-endowed provinces or regions. By asking how much funding the cooperative has received and via which channels, we found that subsidies and financial support are not equally distributed among farmers' cooperatives, even those in the same region. These funding opportunities have each been channeled to cooperatives via various government development projects, such as the Rural Poverty Alleviation program, the Upland and Mountainous Area Development Project, and the High-efficiency Agriculture Project. Our case studies found that cooperative initiators and/or leaders who have contacts in relevant government departments and are socially well connected have played an important role in acquiring funding information and preparing funding applications. ${ }^{20}$

Financial support and subsidies for rural development typically take the form of investment in rural infrastructure, crop storage, and processing facilities. This investment is especially important for cooperatives struggling to raise capital at the start-up stage. According to our interviews, in all three cases a significant amount of government funding had been used for improving village roads. Although this type of government funding was not explicitly linked to support for cooperatives, it has played an important role in better linking coopera-

\footnotetext{
${ }^{19}$ Interview with three government officials and two cooperative leaders in Anhui, Jiangsu, Zhejiang provinces, various dates during 2010-2011.

${ }^{20}$ Interview with the leaders of the Yuexi and Daizhuang FPCs, July 26, 2010, and June 1, 2011, respectively.
} 
tives to outside markets. The Daizhuang FPC received interest-free loans of US $\$ 35,000$ to purchase rice processing equipment. Financing for the drip irrigation systems installed by the Tonglu cooperative was partially supported by the Zhejiang provincial and municipal government. The installation of a drip irrigation system helps minimize water contamination from fertilizer and pesticide runoff, and also reduces labor inputs by avoiding the need for irrigating by hand. To host a local agricultural festival, the Tonglu government had also provided substantial funding each year since 2008 to improve village infrastructure and increase the attractiveness of the village to tourists. Beyond protecting and promoting rural lifestyle and culture, this festival also works as a marketing strategy to help advertise the cooperative and expand the reputation of its products.

Local governments also support cooperatives by providing technical training and product promotion by establishing product brands. For the Daizhuang FPC, the municipal government assisted in establishing collaboration between the cooperative and several agricultural universities in the surrounding areas. The Tonglu FPC had four technicians, all of whom had attended technical training sessions organized and financed by the Bureau of Agriculture in Tonglu county. These training sessions were offered by experts and researchers from Zhejiang University and the Academy of Agricultural Science at the city and provincial levels. After attending training courses three to four times per year for two to three years, the leader and these technicians established an extension program in 2004 to provide on-site technical support to local farmers. The Yuexi FPC was mainly initiated by the GTZ project, and local government agencies played a small role in the early stages. Since the GTZ project ended, local government has started to play a more important role, especially in assisting with hazard-free and GI (geographical indication) certification for all water bamboo produced in Yuexi county. The Yuexi county government established a special department to promote certified agricultural products, mainly hazard-free and green food, to take advantage of the county's abundant natural resources with low contamination.
In addition to these various forms of tangible support, local government has also provided public recognition to selected cooperatives as a reward for their good performance. The Daizhuang FPC was honored by the Ministry of Agriculture with national-level "Model FPC" recognition in 2012. The Tonglu FPC also received many awards and honors from the government, such as city- and provincial-level "Model PFC" recognition.

\section{Discussion}

\section{Cooperatives' Contributions to Rural Development}

In this study we examined a series of diversified land-based activities adopted by three farmers' professional cooperatives engaging in ecological agricultural production in three provinces of China. These activities have a range of different expressions, including capturing greater value-added in production via certification, branding, processing, sorting, and packaging (found in all three FPCs); shortening supply chains (for example, providing home delivery and operating local specialty stores in the Daizhuang FPC); and expanding to other on-farm activities (for example, agritourism in the Tonglu FPC). Rural systems with strong multifunctionality can offer diverse opportunities for residents in terms of earning non-agricultural income (e.g., agritourism), maintaining high environmental quality, and increasing stakeholder involvement and rural democracy (Wilson, 2010). We categorized the diversified rural development activities into three alternative strategies: deepening, broadening, and regrounding. We assessed the economic, social, and environmental impacts of farmers' cooperatives associated with adopting these activities and strategies. This provided a sense of their contributions to agricultural multifunctionality and rural development.

In all three cases the economic contribution of FPCs to rural development is significant. Members in all three FPCs have reported a significant increase of their household income from agricultural production. For example, the average household income of members of the Daizhuang FPC increased by approximately RMB 5000 (US\$310) in 2010. By taking advantage of economies of scale FPCs help overcome the limitations of small-scale 
farming in terms of supplying input, marketing outputs, reducing transaction costs, enhancing the safety and quality of agricultural production, increasing market competitiveness, and expanding new markets or value chains. The "deepening" activities enhance the economic empowerment of small-scale farmers by linking them to value-added markets (e.g., ecological and organic products, branding, processing, sorting, and packaging). Beyond producing food, the Tonglu FPC also adopted a broadening strategy (i.e., agritourism) to help advertise the cooperative and increase the reputation of its products. Through united management and collective decision-making, the "regrounding" activities provide economic contributions to farm members by reducing production and transaction costs, and responding more effectively to market demands. These diversified activities contribute significantly to improving household incomes and living conditions of cooperative members, which are also the goals of current agricultural policies.

All three FPCs have experienced substantial growth in cooperative membership since their establishment. As the leader of the Tonglu FPC explained,

Since our cooperative was founded, many strategies have been adopted, such as branding, certification, sorting and packaging, direct marketing, etc. These strategies have helped increase the prices of our products. Our members now receive higher economic returns from farming. So farmers in our village and those in surrounding villages all want to join in our cooperative. But our cooperative only accepts new members who meet our stringent selection criteria, like willingness to follow the cooperative rules and our production standards, self-discipline, etc.

Given the fact that farmers differ in their financial assets, skills, and social networks, economic benefits of the cooperatives are not distributed equally among members. In addition to selling agricultural products to the FPC, some core members also invest capital in the FPC that gets used for purchasing inputs, processing and sorting machines, and cold storage facilities. They have both user shares and investor shares ${ }^{21}$ in the FPC. Therefore, these core members often hold more shares and correspondingly benefit more from the FPC, whereas common members only benefit by selling their products to the FPC (see also Liang \& Hendrikse, 2013).

Farmers' cooperatives have also made important social contributions to rural development. The social contributions revealed in our case studies can be categorized into four aspects: social integration, local and regional embeddedness, adoption of food quality standards and food safety, and rural democracy and governance. We will discuss each of these in turn. First, in terms of social integration, on the one hand, the farmers' cooperative model provides a platform for farm members to exchange experiences and gain new knowledge, which further reinforces the ties and enhances social integration among members. On the other hand, through collaborating with other cooperatives, universities, and research institutes, farmers' cooperatives have enhanced their capacity to network with other actors. However, in our case studies we found that the integration among cooperatives was still very loose, partially because the newly enacted Cooperative Law does not define a cooperative federation (i.e., a supracooperative network). This omission could pose significant constraints for cooperatives to grow and gain strength in the global market (Fleischer, 2012).

Second, in terms of local and regional embeddedness, direct-marketing strategies adopted by the Tonglu and Daizhuang FPCs helped reconnect producers and consumers and renegotiate the trust relationship between them, which further contributed to high levels of social embeddedness and relations of regard (Hinrichs, 2000; Milestad, Bartel-Kratochvil, Leitner, \& Axmann, 2010). The degree of local and regional embeddedness of the food supply chain is an important indicator of rural development (Knickel, 2001) and a strongly multifunctional agriculture regime (Clark, 2003).

In terms of the third element of social contrib-

${ }^{21}$ According to the FPC law, no single member can hold more than 20 percent of the total investor share in the cooperative. 
utions to rural development, each cooperative in our case study adopted certain types of food quality production standards and registered a brand for their products, which would facilitate food safety in China (see also Jin \& Zhou, 2011). In addition, as the main actors in FPCs, farmers gained experience in cooperation and democratic governance by electing cooperative leaders and participating in decision-making (although this was limited to the production domain for common members in our case studies).

Environmental contributions of farmers' cooperatives to rural development can also be found in all three FPCs. All three engaged in ecological agriculture (green, hazard-free food and organic agriculture in our cases), which helps to build soil fertility and minimize environmental externalities. Localized food supply chains established by the Daizhuang and Tonglu FPCs reduce the distance that food travels from the site of production to consumption, thereby reducing the need for long-distance food transport and its associated energy emissions (Goodman, 2004). Agritourism can help improve the awareness of environmental problems among both farmers and urban visitors (Brodt, Feenstra, Kozloff, Klonsky, \& Tourte, 2006).

\section{Challenges Facing Farmers' Professional Cooperatives} Although FPCs have developed rapidly in China over the past decade, progress has not been uniform across the country due to differences in farmers' education levels and varying economic and social situations among different regions of the country (Garnevska et al., 2011), as well as varying levels of government support, and of trust among farmers. FPCs face many challenges for developing further. In our study, the major challenges faced by cooperatives included limited access to land and capital, a massive loss of young and educated laborers in the agricultural sector, low market competitiveness, weak internal management, and limited government support.

Under the Household Responsibility System (HRS), China's agricultural sector is dominated by small-scale farms, with an average size of less then 0.5 hectares per household (1.2 acres), typically fragmented into four to six noncontiguous plots
(Johnson, 2000). As a result of the small scale of land allocated to each household, the economic return of farming is low, which has in turn caused large-scale rural outmigration of young and educated people (Zhang et al., 2002). Part-time farming is very common in rural China, as we found in all three FPCs. For all of these reasons, it is not surprising to see low motivation for farming among cooperative members. In addition, farming has been viewed as "a low status occupation to be avoided" by the young generation (Rigg, 2006, p. 189). Therefore, young and educated people often choose to work in non-agricultural sectors.

Due to the small-scale units of production and low economic returns from farming, lack of financial resources is a common issue faced by farmers and farmers' cooperatives in China. FPCs have difficulty obtaining loans from banks using land as collateral because rural land is collectively owned and farmers have only limited land-use rights under the HRS. ${ }^{22}$ In our study, none of the three FPCs mentioned that loans had been provided to their members. The absence of lending services in cooperatives in China might stem from credit not being included on the list of cooperative activities described in the newly enacted Cooperative Law (Deng, Huang, Xu, \& Rozelle, 2010). Because cooperatives in China have limited financial resources and do not qualify for loans, the access to external financial support, often from government, is critical for FPCs in order to purchase expensive facilities and equipment. We found in this study that cooperatives with strong government support were better positioned for economic success. Moreover, by using their guanxi (informal networks) cooperative initiators can often play an important role in identifying and accessing government funding opportunities. However, relying heavily on the initiator for technical, financial, and marketing support may cause problems for FPCs when external forces withdraw. Members in the Daizhuang FPC expressed their concerns about the future of their cooperative when the initiator could not longer help with securing government funding

\footnotetext{
${ }^{22}$ Land in the countryside and in suburban areas is under collective ownership unless the law stipulates that the land is state-owned (National People's Congress 1982, Article 10).
} 
and promoting their cooperative and its products.

Low market competitiveness was also a significant challenge for FPCs because of limited access to market information, difficulty in expanding markets, and lack of technical innovation. For most Chinese peasants, farming is the only area in which they have practical experience. Many organic farms in China face difficulties in further expanding markets, especially for value-added products (Pan \& Du, 2011; Thiers, 2005). This challenge arose in all three FPCs. The leader of Daizhuang FPC mentioned the difficulties in expanding markets due to its low capacity to invest and the small volume of production to supply major food retailers. This also posed challenges for recruiting more members and expanding its production scale. The Yuexi FPC failed to sell its organic products on the international market with a price premium and had to discontinue organic certification after the GTZ project ended. Although all three FPCs have applied technical innovations to improve their market competitiveness, this could not have been achieved without strong external support. For example, to improve market competitiveness, the Daizhuang FPC introduced a new rice variety from Japan and the Tonglu FPC applied a new practice to stagger the harvest time of peaches to fill supply gaps in the market.

Weak internal management was also a key challenge for FPCs, consisting of low trust among members, lack of effective and dedicated leadership, and passive participation by members. These factors have further raised issues of trust among core and common members and cooperative leaders, an issue that was raised by all three FPCs. The effective operation of farmers' cooperatives requires a high level of cooperation among members to achieve the economy of scale as a single unit (Ortiz-Miranda et al., 2010). Questionnaire surveys in other contexts have found that the level of trust is significantly linked to economic performance (Knack \& Keefer, 1997) and citizen participation (Brehm \& Rahn, 1997). Lu, Kormelinck, Muradin, Lu, and Ruben (2012) found that members in economically successful FPCs show a higher level of trust with fellow members than those in weakly performing ones. Conversely the low operational efficiency in some FPCs in
China has been linked to a lack of trust between and among farm members and the cooperative (Guo, Yang, \& Zhang, 2008; Zhang, 2010). The lack of trust has become a social problem and could inhibit the long-term development of Chinese FPCs (Zhang, 2010). In addition, Xu, Shao, Liang, Guo, Lu, and Huang (2013) also pointed out that many FPCs in China have internal governance problems, including overly informal management structures and financial systems. In addition, the part-time farming status limits the level of involvement of common members in cooperative activities. As one core member in the Daizhuang FPC explained,

It's May and it's the time for rice seedling production now. Farmers only come back to the village for one or two days to do the work. Now you can see that there are no people in the field to take care of these seedlings. They all work in cities through the slack farming season, leaving their farmland unattended....So, it's unrealistic for us to organize cooperative meetings regularly and let members participate actively.

The results of this study echo the finding of Banaszak (2008) that initiators and leaders are critically important for the successful development of FPCs, especially in the context of China where the majority of farmers farm at a very small scale, have a low level of education and technical skills, and lack social and capital resources. Many cooperatives lack effective and dedicated leadership, as we found in the Yuexi FPC after the previous leader retired. The fact that village officials also serve as cooperative leaders (as in the Daizhuang FPC) might benefit the rural economy and consolidate their position as village officials, but it could also pose challenges for FPCs with respect to democratic management, limited personal energy, and difficulties in separating finance issues between the village as an administrative unit and the FPC as an economic unit. How to enhance internal management is a major issue both for FPCs and the Chinese government. 


\section{Conclusions}

Several conclusions can be drawn from our comparative case study. First, in adopting the "deepening-broadening-regrounding" typology of van der Ploeg et al. (2002) for our analysis, we found that the deepening and regrounding strategies were more commonly applied by all three FPCs than the broadening strategy. Broadening activities, such as agritourism, are more challenging for China's FPCs because of their high economic risks and the requirements for capital investment and new management and marketing skills. Second, our case studies demonstrate the potential of FPCs to make significant economic, social, and environmental contributions to rural development. However, our interviews suggest that economic gains are not shared equally among members in the cooperative. Common members only benefit by selling their products to the cooperative, whereas core members can benefit by both selling their products to and investing capital in the cooperative.

Third, FPCs in China also face enormous challenges, including limited access to land and capital, a massive loss of young talent, low market competitiveness, weak internal management, and lack of government support in poor areas. Fourth, the Chinese government has played an important role in establishing a supportive environment for cooperative development, mainly through (1) implementing the Cooperative Law and developing a series of favorable policies, (2) intervening directly in the establishment and operation of cooperatives, and (3) providing various forms of financial support (e.g., subsidies, tax exemption, and preferential loans) and nonfinancial support (e.g., technical and marketing assistance and public recognition). The strong government role in promoting FPCs we found in this study confirms previous research that rural development is spurred in large part by the Chinese government, which differs from European countries where rural development has been driven by farmers' initiatives and activities (van der Ploeg et al., 2012). Even though FPCs have played and can play an increasingly important role in rural development, we acknowledge that large enterprises (particularly dragon-head enterprises) will continue to dominate the Chinese agricultural sector and receive strong government support (Huang, 2011; Xu et al., 2013). This research is just a starting point, and we hope it will inspire further research in this important field. It would be insightful to have follow-up research examine both successful and less successful cases of cooperatives to shed more light on the obstacles that cooperatives have encountered and the major elements behind successful cooperatives in China. Due to differences in economic and social contexts, the development of FPCs varies across regions and provinces in China. The impacts of FPCs on small-scale farms and rural development also vary in practice, so it would be valuable to do comparative studies of cooperatives in different regions and provinces. In addition, in this study we found that cooperative benefits are not equally distributed among members because of the differences in assets and resources. A fruitful direction for future research would be to explore whether there is a connection between these different "classes" of membership and the extent of decision-making in and economic benefits from FPCs. Such research could challenge assumptions about how equitable FPCs are in practice.

\section{Acknowledgments}

We would like to thank the editors and anonymous reviewers for valuable feedback on this paper. We also acknowledge funding from the Social Sciences and Humanities Council of Canada for funding the fieldwork on which this paper was based.

\section{References}

Banaszak, I. (2008). Determinants of successful cooperation in agricultural markets: Evidence from producer groups in Poland. In G. Hendrikse, M. Tuunanen, J. Windsperger, \& G. Cliquet (Eds.), Strategy and governance of networks: cooperatives, franchising, and strategic alliances (pp. 27-46). http://dx.doi.org/10.1007/978-3-7908-2058-4 3

Bao, Z. (2002). Zhongguo pinkun diqu youji nongye xiangmu: Yuexi xiangmudian [The report of organic agricultural development projects in less-developed regions in China: Organic agricultural development in Yuexi County]. Unpublished report.

Barrett, C. B. (2008). Smallholder market participation: Concepts and evidence from eastern and southern Africa. Food Policy, 33(4), 299-317. http://dx.doi.org/10.1016/j.foodpol.2007.10.005 
Birchall, J. (2004). Cooperatives and the Millennium Development Goals. Geneva: International Labour Office. Retrieved from http://www.ilo.org

Bosc, P. M., Eychenne, D., Hussein, K., Losch, B., Mercoiret, M. R., Rondot, P., \& Mackintosh-Walker, S. (2002). The role of rural producer organizations in the World Bank rural development strategy (Rural strategy background paper No. 8). Washington, D.C. : The World Bank. Retrieved from http://documents.worldbank.org/curated/en/2002 /03/2081039/role-rural-producer-organizationsworld-bank-rural-development-strategy

Brehm, J., \& Rahn, W. M. (1997). Individual-level evidence for the causes and consequences of social capital. American Journal of Political Science, 41(3), 9991023. http://www.jstor.org/stable/2111684

Brodt, S., Feenstra, G., Kozloff, R., Klonsky, K., \& Tourte, L. (2006). Farmer-community connections and the future of ecological agriculture in California. Agriculture and Human V alues, 23, 75-88. http://dx.doi.org/10.1007/s10460-004-5870-y

Chan, H. (2009). Politics over markets; integration sateowned enterprises into Chinese socialist market. Public Administration and Development, 29: 43-54. http://dx.doi.org/10.1002/pad.502

Choi, J., Kim, J., Kim, J., \& Kim, J. (2007). Improving community-driven development strategy: The case of New Village Movement in Korea. Retrieved from http://info.worldbank.org/etools/docs/voddocs/ 955/2101/lo.htm

Clark, J. R. A. (2003). Regional innovation systems and economic development: The promotion of multifunctional agriculture in the English East Midlands (Doctoral dissertation). Department of Geography, University College London. Retrieved from EThOS: http://ethos.bl.uk/

Clegg, J. (2006). Rural cooperative in China: Policy and practice. Journal of Small Business and Enterprise Development, 13(2), 219-234. http://dx.doi.org/10.1108/14626000610665926

Darnhofer, I. (2005). Organic farming and rural development: Some evidence from Austria. Sociologia Ruralis, 45(4), 308-323. http://dx.doi.org/10.1111/ j.1467-9523.2005.00307.x

Deng, H., Huang, J., Xu, Z., \& Rozelle, S. (2010). Policy support and emerging farmer professional cooperatives in rural China. China Economic Review,
21(4), 495-507.

http://dx.doi.org/10.1016/j.chieco.2010.04.009

Durand, G \& van Huylenbroeck, G. (2003). Multifunctionality and rural development: A general framework. In G. van Huylenbroeck \& G. Durand (Eds.), Multifunctional agriculture: A new paradigm for European agriculture and rural development (pp. 1-16). Aldershot, UK: Ashgate.

Fan, S., \& Zhang, X. (2004). Infrastructure and regional economic development in rural China. China Economic Review, 15(2), 203-214. http://dx.doi.org/10.1016/j.chieco.2004.03.001

Fleischer, G. (2012). Between organic development and state control. Rural Focus: International Journal for Rural Development, 21, 23-25. Retrieved from http://www.rural21.com/english/a-closer-lookat/detail/article/between-organic-developmentand-state-control-0000305/

Fleischer, A., \& Felsenstein, D. (2000). Support for small-scale rural tourism: Does it make a difference? Annals of Tourism Research, 27(4), 1007-1024. http://dx.doi.org/10.1016/S0160-7383(99)00126-7

Gannon, A. (1994). Rural tourism as a factor in rural community economic development for economies in transition. Journal of Sustainable Tourism 2(1-2), 51-60. http://dx.doi.org/10.1080/09669589409510683

Garnevska, E., Liu, G., \& Shadbolt, N. M. (2011). Factors for successful development of farmer cooperatives in northwest China. International Food and Agribusiness Management Review, 14(4), 69-84. Retrieved from http://ageconsearch.umn.edu/ bitstream/117603/2/20110028 Formatted.pdf

Goodman, D. (2004). Rural Europe redux? Reflections on alternative agro-food networks and paradigm change. Sociologia Ruralis, 44(1), 3-16. http://dx.doi.org/10.1111/j.1467-9523.2004. $\underline{00258 . x}$

Guo, H., Yang, H., \& Zhang, R. (2008). Yingxiang nongmin zhuanye hezuoshe sheyuan dui shezhang xinren de yinsu fenxi: Jiyu zhejiangsheng bufen sheyuan de diaocha [Study on the factors influencing cooperative members' trust on the cooperative leader: A case study on the cooperative members in Zhejiang Province]. China Rural Economy, 8, 52-60. http://wenku.baidu.com/view/ b5b3949951e79b89680226c0.html 
Gürel, B. (2014). Changing relations of production in Chinese agriculture from decollectivization to capitalism. McGill Sociological Review, 4, 67-92. https://www.mcgill.ca/msr/

Hale, M. A. (2013). Reconstructing the rural: Peasant organizations in a Chinese movement for alternative development (Doctoral dissertation). University of Washington, Seattle, Washington. Retrieved from http://hdl.handle.net/1773/23389

Hinrichs, C. C. (2000). Embeddedness and local food systems: Notes on two types of direct agricultural market. Journal of Rural Studies, 16(3), 295-303. http://dx.doi.org/10.1016/S0743-0167(99)00063-7

Hu, D., Reardon, T., Rozelle, S., Timmer, P., \& Wang, H. (2004). The emergence of supermarkets with Chinese characteristics: Challenges and opportunities for China's agricultural development. Development Policy Review, 22(5), 557-586. http://dx.doi.org/10.1111/j.14677679.2004.00265.x

Huang, P. C. C. (2011). China's new-age small farms and their vertical integration: Agribusiness or co-ops? Modern China, 37(2), 107-134. http://dx.doi.org/10.1177/0097700410396476

International Co-operative Alliance. (n.d.). Co-operative identity, values \& principles. Retrieved from http://ica.coop/en/whats-co-op/co-operativeidentity-values-principles

Iorio, M., \& Corsale, A. (2010). Rural tourism and livelihood strategies in Romania. Journal of Rural Studies, 26(2), 152-162. http://dx.doi.org/10.1016/j.jrurstud.2009.10.006

Jia, X., Hu, Y., Hendrikse, G., \& Huanga, J. (2010, June). Centralized versus individual: Governance of farmer professional cooperatives in China. Paper presented at the IAMO Forum, Halle (Saale), Germany. Retrieved from the EconPapers website: http://EconPapers.repec.org/RePEc:zbw:iamo10:5 2699

Jin, S., \& Zhou, J. (2011). Adoption of food safety and quality standards by China's agricultural cooperatives. Food Control, 22(2), 204-208. http://dx.doi.org/10.1016/j.foodcont.2010.06.021

Johnson, D. G. (2000). Agricultural adjustment in China: Problems and prospects. Population and Development Review, 26(2), 319-334. http://dx.doi.org/10.1111/ j.1728-4457.2000.00319.x

Kirschenmann, F., Stevenson, G. W., Buttel, F., Lyson, T. A., \& Duffy, M. (2008). Why worry about the agriculture of the middle? In T. A. Lyson, G. W. Stevenson, \& R. Welsh (Eds.), Food and the mid-level farm: Renewing an agriculture of the middle (pp. 3-22). Cambridge, Massachusetts: MIT Press.

Knack, S., \& Keefer, P. (1997). Does social capital have an economic pay-off? A cross-country investigation. Quarterly Journal of Economics, 112(4), 1251-1288. http://dx.doi.org/10.1162/003355300555475

Knickel, K. (2001). The marketing of Rhöngold milk: An example of the reconfiguration of natural relations with agricultural production and consumption. Journal of Environmental Policy and Planning, 3(2), 123-136. http://dx.doi.org/10.1002/jepp.79

Knickel, K., \& Renting, H. (2000). Methodological and conceptual issues in the study of multifunctionality and rural development. Sociologia Ruralis, 40(4), 512 528. http://dx.doi.org/10.1111/1467-9523.00164

Kruijssen, F., Keizer, M., \& Giuliani, A. (2009). Collective action for small-scale producers of agricultural biodiversity products. Food Policy, 34(1), 46-52. http://dx.doi.org/10.1016/i.foodpol.2008.10.008

Lagos, J. E., Scott, R. R., Rasmussen, K., Bugang, W., \& Chen, U. (2010). Organic Report, China - People's Republic of (GAIN Report No. 10046). Retrieved from http://gain.fas.usda.gov/

Lammer, C. (2012). Imagined cooperatives: An ethnography of cooperation and conflict in new rural reconstruction projects in a Chinese village (Doctoral dissertation). University of Vienna, Austria. Retrieved from http://othes.univie.ac.at/21503/1/2012-0719 0400999.pdf

Liang, Q., \& Hendrikse, G. (2013). Core and common members in the genesis of farmer cooperatives in China. Managerial and Decision Economics, 34(3-5), 244-257. http://dx.doi.org/10.1002/mde.2587

Long, H., Liu, Y., Li, X., \& Chen, Y. (2010). Building new countryside in China: A geographical perspective. Land Use Policy, 27(2), 457-470. http://dx.doi.org/10.1016/j.landusepol.2009.06.006

Lu, H., Kormelinck, A., Muradin, R., Lu, X., \& Ruben, R. (2012, June). Trust in Chinese agric-food cooperatives: A games approach. Paper presented at the meeting of the International Food and Agribusiness Management Association, Shanghai. Retrieved from the Berenschot website: http://www.berenschot. $\mathrm{nl} / \mathrm{publish} /$ pages/2154/trust in chinese agrifood cooperatives- a games approach _lu_kormelink_muradin_lu_ruben.doc 
Marsden, T. (2003). The condition of rural sustainability. Assen, the Netherlands: Koninklijke Van Gorcum.

Marsden, T. (2009). Mobilities, vulnerabilities and sustainabilities: Exploring pathways from denial to sustainable rural development. Sociologia Ruralis, 49(2), 113-131. http://dx.doi.org/10.1111/j.14679523.2009.00479.x

Marsden, T., Banks, J., \& Bristow, G. (2002). The social management of rural nature: Understanding agrarian-based rural development. Environment and Planning A, 34(5), 809-825. http://dx.doi.org/10.1068/a3427

Marsden, T., Murdoch, J., Lowe, P., Munton, R. C., \& Flynn, A. (1993). Constructing the countryside: An approach to rural development. London: UCL Press.

Marsden, T., Yu, L., \& Flynn, A. (2011). Exploring ecological modernisation and urban-rural ecodevelopments in China: The case of Anji County. Town Planning Review, 82(2), 195-224. http://dx.doi.org/10.3828/tpr.2011.13

Milestad, R., Bartel-Kratochvil, R., Leitner, H., \& Axmann, P. (2010). Being close: The quality of social relationships in a local organic cereal and bread network in Lower Austria. Journal of Rural Studies, 26(3), 228-240. http://dx.doi.org/10.1016/j.jrurstud.2010.01.004

National People's Congress [NPC]. (2006). The farmer specialized co-operatives law (enacted in 2007).

Ortiz-Miranda, D., Moreno-Pérez, O. M., \& MoraguesFaus, A. M. (2010). Innovative strategies of agricultural cooperatives in the framework of the new rural development paradigms: The case of the region of Valencia (Spain). Environment and Planning A, 42(93), 661-677. http://dx.doi.org/10.1068/a42168

Paldam, M., \& Svendsen, G. T. (2002). Missing social capital and the transition in Eastern Europe. Journal for Institutional Innovation, Development and Transition, 5, 21-34.

Pan, J., \& Du, J. (2011). The social economy of new rural reconstruction. China Journal of Social Work, 4(3), 271-282. http://dx.doi.org/10.1080/17525098.2011.615385

Renting, H., Marsden, T. K., \& Banks, J. (2003). Understanding alternative food networks: Exploring the role of short food supply chains in rural development. Environment and Planning A, 35(3), 393-411. http://dx.doi.org/10.1068/a3510
Renting, H., Rossing, W. A. H., Groot, J. C. J., van der Ploeg, J. D., Laurent, C., Perraud, D., Stobbelaar, D. J., \& Van Ittersum, M. K. (2009). Exploring multifunctional agriculture. A review of conceptual approaches and prospects for an integrative transitional framework. Journal of Environmental Management, 90(Supp. 2), S112-S123. http://dx.doi.org/10.1016/j.jenvman.2008.11.014

Rigg, J. (2006). Land, farming, livelihoods, and poverty: Rethinking the links in the rural South. World Development, 34(1), 180-202.

http://dx.doi.org/10.1016/j.worlddev.2005.07.015

Scott, S., Si, Z., Schumilas, S., \& Chen, A. (2014). Contradictions in state- and civil society-driven developments in China's ecological agriculture sector. Food Policy, 45, 158-166. http://dx.doi.org/10.1016/i.foodpol.2013.08.002

Sharpley, R. (2002). Rural tourism and the challenge of tourism diversification: The case of Cyprus. Tourism Management, 23(3), 233-244. http://dx.doi.org/10.1016/S0261-5177(01)00078-4

Si, Z., Schumilas, T., \& Scott, S. (in press). Characterizing alternative food networks in China. Agriculture and Human V alues.

Sultan, T. \& K. Larsén. (2011). Do institutional incentives matter for farmers to join cooperatives: A comparison of two Chinese regions. Journal of Rural Cooperation, 39(1), 1-18. http://departments. agri.huji.ac.il/econocen/en/jrc.htm

Thiers, P. (2005). Using global organic markets to pay for ecologically based agricultural development in China. Agriculture and Human Values, 22(1), 3-15. http://dx.doi.org/10.1007/s10460-004-7226-z

Tisenkopfs, T., Kovách, I., Lošt’ák, M., \& Šūmane, S. (2010). Rebuilding and failing collectivity: Specific challenges for collective farmers marketing initiatives in post-socialist countries. International Journal of Sociology of Agriculture and Food, 18(1), 70-88. Retrieved from http://www.ijsaf.org/archive/18/1/tisenkopfs.pdf

United Nations. (2001). Cooperatives in social development: Report of the secretary-general. Geneva: Author. Retrieved from http://www.un.org/documents/ ecosoc/docs/2001/e2001-68.pdf

van der Ploeg., J. D. (2000). Revitalizing agriculture: Farming economically as starting ground for rural development. Sociologia Ruralis, 40(4), 497-511. http://dx.doi.org/10.1111/1467-9523.00163 
van der Ploeg, J. D., Laurent, C., Blondeau, F., \& Bonnafous, P. (2009). Farm diversity, classification schemes and multifunctionality. Journal of Environmental Management, 90(Supp. 2), S124-S131. http://dx.doi.org/10.1016/i.jenvman.2008.11.022

van der Ploeg, J., Long, A., \& Banks, J. (2002). The socio-economic impact of rural development processes within Europe. In J. D. van der Ploeg, J. Banks, \& A. Long (Eds.), Living countrysides: Rural development processes in Europe - The state of the art. Doetinchem, the Netherlands: Elsevier. van der Ploeg, J. D., Jingzhong, Y., \& Schneider, S. (2012). Rural development through the construction of new, nested, markets: Comparative perspectives from China, Brazil and the European Union. Journal of Peasant Studies, 39(1), 133-173. http://dx.doi.org/10.1080/03066150.2011.652619 van der Ploeg, J. D., Renting, H., Brunori, G., Knickel, K., Mannion, J., Marsden, T., de Roest, K., SevillaGuzmán, E., \& Ventura, F. (2000). Rural development: From practices and policies towards theory. Sociologia Ruralis, 40(4), 391-408. http://dx.doi.org/10.1111/1467-9523.00156

Wen, T., \& Dong, X. (2010). Cunshe lixing: Pojie "sannong" yu "sanzhi" kunjing de yige xin shijiao [Village-community rationality: A new perspective to solve the predicaments of 'sannong' and 'sanzhi']. Journal of the Party School of the Central Committee of the CPC, 14(4), 20-23. http://irrc.swu.edu.cn/viscms/ u/cms/irrc/201404/190017237sla/村社理性破解 三農与三治困境的一個新視角.pdf

Wilson, G. (2010). Multifunctional 'quality' and rural community resilience. Transactions of the Institute of British Geographers, 35(3), 364-381. http://dx.doi.org/10.1111/j.1475-5661.2010. $\underline{00391 . x}$

Xiaoshan, Z. (1999). Cooperatives, communities and the state: The recent development of Chinese rural cooperatives in transition. Land Reform, Land Settlement and Cooperatives, 1-2, 92-105. Available at: ftp://ftp.fao.org/sd/SDA/SDAA/Lr99/X3720T0 $\underline{\text { 8.pdf }}$

Xu, X., Shao, K., Liang, Q., Guo, H., Lu, J., \& Huang, Z. (2013). Entry of Chinese small farmers into big markets: From enterprise-led structures to farmer cooperatives. The Chinese Economy, 46(1), 7-19. http://dx.doi.org/10.2753/CES1097-1475460101

Yan, H., \& Chen, Y. (2013). Debating the rural cooperative movement in China, the past and the present. Journal of Peasant Studies, 40(6), 955-981. http://dx.doi.org/10.1080/03066150.2013.866555

Yang, S., \& Wen, T. (2011). Nongmin zuzhihua de kunjing yu chulu [The predicament of and solution to farmers' organization]. People's Forum, 29, 44-45. http://www.snzg.cn/article/2011/1119/article 26 308.html

Yin, R. K. (2003). Case study research: Design and methods (3rd Ed.). Thousand Oaks, California: SAGE.

Zhang, L., Huang, J., \& Rozelle, S. (2002). Employment, emerging labor markets, and the role of education in rural China. China Economic Review, 13 (2-3), 313 328. http://dx.doi.org/10.1016/S1043-951X(02) 00075-5

Zhang, Y. (2010). Xinren queshi zhiyue nongcun zhuanye hezuoshe de fazhan fenxi [Analysis on the lack of trust on the development of cooperatives]. Agricultural Economics, 1, 38-39. http://wenku.baidu.com/view/0586cd0e22791688 $\underline{8486 \mathrm{~d} 772 . \mathrm{html}}$

Zhao, Y. (1999). Labor migration and earnings differences: The case of rural China. Economic Development and Cultural Change, 47(4), 767-782. http://dx.doi.org/10.1086/452431 